УДК 578.76

https://doi.org/10.17816/MAJ19337-46

\title{
EARLY PROTECTION AGAINST INFLUENZA BY PANDEMIC LIVE ATTENUATED INFLUENZA VACCINES
}

\author{
A.R. Rekstin, J.A. Desheva, I.N. Isakova-Sivak, I.V. Kiseleva
}

Institute of Experimental Medicine, Saint Petersburg, Russia

For citation: Rekstin AR, Desheva JA, Isakova-Sivak IN, Kiseleva IV. Early protection against influenza by pandemic live attenuated influenza vaccines. Medical Academic Journal. 2019;19(3):37-46. https://doi.org/10.17816/MAJ19337-46

Received: July 24, 2019

Revised: August 6, 2019

Accepted: August 29, 2019

Live attenuated cold-adapted (ca) influenza vaccine (LAIV) is an effective tool for the control of influenza, most likely due to their ability to induce both humoral and cellular immune responses, easy application and relatively low manufacturing costs. Attenuated cold-adapted vaccine strains that have achieved a satisfactory balance between restricted replication and high immunogenicity are desirable. The immunogenicity of live attenuated vaccines may depend upon the interplay between its ability to induce pro-inflammatory cytokine responses and the relative sensitivity of the attenuated vaccine strain to an antiviral effect of these cytokines. To better understand the relationship between attenuation and induction of innate immunity as well as contribution of the early cytokine response to the relative immunogenicity of LAIVs, we have studied early protection induced by LAIV in vivo as well as early cytokine response in human cells macrophage origin in response to infection with vaccine strains or epidemic virus.

The aim of this study was to investigate the early immune response and protective activity in female CBA mice intranasally immunized with cold-adapted influenza vaccine strains of different genome compositions of 5:3 or 6:2. For experimental infection pandemic influenza viruses A/South Africa/3626/13 (H1N1)pdm09 and A/New York/61/15 (H1N1)pdm09 were used to be administered to animals at a dose of $10^{6} \mathrm{EID}_{50}$ at day 3 after immunization (challenge infection). Although challenge viruses replicate at mice lungs at various, extend, on day 10 after immunization mice were protected from death from 60 up to $80 \%$. Reassortants LAIV did not differ statistically on these levels.

Study of the expression of IFN- $\alpha$ and IFN- $\beta$ genes in human lung macrophage line cells THP-1 in vitro have shown that macrophages stimulated with vaccine strains with the genome formula $6: 2$ and $5: 3$, had a sufficient level of expression of these genes, comparable to that, as in infection with wild virus type A/South Africa/3626/13 (H1N1)pdm09. These data may indicate that surface proteins of influenza A virus are involved in the process of stimulation of the IFN- $\alpha$ and IFN- $\beta$ genes.

Keywords: influenza; live attenuated influenza vaccine; innate immunity; cytokines.

\section{РАННЯЯ ЗАЩИТА ОТ ГРИППА С ПОМОЩЬЮ ПАНАЕМИЧЕСКИХ ЖИВЫХ ГРИППОЗНЫХ ВАКЦИН}

\author{
А.Р. Рекстин, Ю.А. Аешева, И.Н. Исакова-Сивак, И.В. Киселева \\ ФГБНУ «Институт экспериментальной медицины», Санкт-Петербург
}

Для цитирования: Рекстин А.Р., Дешева Ю.А., Исакова-Сивак И.Н., Киселева И.В. Ранняя защита от гриппа с помощью пандемических живых гриппозных вакцин // Медицинский академический журнал. - 2019. - Т. 19. - № 3. - C. 37-46. https://doi. org/10.17816/MAJ19337-46

Поступила: 24.07.2019 Одобрена: 06.08.2019

Принята: 29.08.2019

Живые аттенуированные холодоадаптированные гриппозные вакцины являются эффективным средством борьбы с гриппом благодаря их способности индуцировать как гуморальные, так и клеточные иммунные реакции, простоте применения и относительно низкой стоимости изготовления. При конструировании вакцин необходимо использовать аттенуированные, адаптированные к холоду вакцинные штаммы, обладающие удовлетворительным балансом между ограниченной репликацией и высокой иммуногенностью. Иммуногенность живых аттенуированных вакцин может зависеть от взаимодействия между их способностью индуцировать провоспалительные цитокиновые реакции и относительной чувствительностью аттенуированного вакцинного штамма к противовирусному действию этих цитокинов. Чтобы лучше понять взаимосвязь между аттенуацией и индукцией врожденного иммунитета, а также вклад раннего цитокинового ответа в относительную иммуногенность живых аттенуированных вакцин против гриппа, мы изучили раннюю защиту, индуцированную живой аттенуированной холодоадаптированной гриппозной вакциной in vivo, а также ранний цитокиновый ответ в клетках макрофагального происхождения человека в ответ на инфицирование вакцинными штаммами или эпидемическим вирусом. 
Цель настоящего исследования заключалась в изучении раннего иммунного ответа и защитной активности у самок мышей линии СВА, интраназально иммунизированных адаптированными к холоду штаммами гриппозной вакцины с формулой генома 5:3 или 6:2. Для экспериментального заражения (челленджа) использовали пандемические вирусы гриппа А/Южная Африка/3626/13 (H1N1)pdm09 и А/Нью-Йорк/61/15 (H1N1)pdm09, которые вводили животным в дозе $6,0 \log _{10}$ ЭИД 50 на 3-и сутки после иммунизации. Хотя пандемические вирусы и реплицировались в легких мышей на протяжении короткого периода времени, в течение 10 дней после иммунизации мыши были защищены от гибели на 60-80\%.

Изучение экспрессии генов IFN- $\alpha$ и IFN- $\beta$ в клетках линии макрофагов легких человека THP-1 in vitro показало, что у макрофагов, стимулированных вакцинными штаммами с формулой генома 6:2 и 5:3, уровень экспрессии этих генов был сопоставим с уровнем, отмечаемым при заражении диким вирусом типа А/Южная Африка/3626/13 (H1N1)pdm09. Эти данные могут свидетельствовать о том, что поверхностные белки вируса гриппа А участвуют в процессе стимуляции генов IFN- $\alpha$ и IFN- $\beta$.

Ключевые слова: гриппозная инфекция; живая гриппозная вакцина; врожденный иммунитет; цитокины.

\section{Introduction}

Influenza viruses cause acute infections of the respiratory tract, which are periodically occurred in the form of epidemics and pandemics and remains one of the major unresolved public health problems worldwide. Each year from 3 to 5 million clinical cases of influenza and 250 to 500 thousand cases with a fatal outcome are recorded [1].

The World Health Organization developed a global plan to prepare for a future influenza pandemic, in which the main attention is paid to vaccination with inactivated or live attenuated influenza vaccines (LAIV). The establishment of the national collections of the vaccine strains against influenza viruses with pandemic potential is one of the priority tasks of Public Health [2].

It is known that the influenza virus infects epithelial cells of the respiratory tract, tissue macrophages, monocytes, and dendritic cells. They all are responsible for the infection by producing a variety of antiviral, proinflammatory and regulatory cytokines and chemokines. It has been shown in studies in animals and humans that the early cytokines, such as interferon $\alpha$ (IFN- $\alpha)$, the tumor necrosis factor $\alpha$ (TNF- $\alpha$ ) and interleukin-6 (IL-6) are key mediators that trigger the immune response and determine the course and outcome of the disease $[3,4]$.

IFN- $\alpha$ has extremely strong antiviral properties; cytokines TNF- $\alpha$ and IL- 6 are responsible for the development of inflammation at the site of infection and are involved in immune activation and recruitment of macrophages. Thus, T- and B-lymphocytes fulfill the role of a bridge between the innate and acquired immune response. On the other hand, the same cytokines may be responsible for acute influenza symptoms and pathology associated with influenza infection, as strong pyrogens and inducers of the production of eicosanoids $[5,6]$.

For the prevention and control of influenza vaccine and antiviral drugs are in use. Clinical studies of LAIVs showed their highest epidemic efficiency in comparison with other options of prevention and treatment of influenza. Live influenza vac- cines are made from attenuated (weakened) strains of the virus, harmless to humans, and are able to form a balanced humoral and cellular immune response $[7,8]$.

It should be noted that in the Department of Virology, Institute of Experimental Medicine a great experience in creating pandemic and seasonal LAIV has been accumulated. Live influenza vaccines have a number of advantages compare to inactivated preparations: they simulate the natural way of virus introduction, and therefore they induce completed adaptive and innate immune responses in the respiratory tract. Furthermore, the use of LAIV is much easier and the production costs are relatively low compared to inactivated vaccines $[9,10]$.

It is shown that multiple mutations in most genes encoding internal proteins of influenza viruses are the basis of the mechanism of attenuation of cold-adapted vaccine strains. Reassortant strains inherit these mutant genes which responsible for attenuation from ca so-called master donor strain (MDS). To date, the features of genetic inheritance by reassortant viruses from parental strains of the major properties like attenuation, temperature sensitivity, cold-adaptation, and the lack of pathogenicity for laboratory animals are well studied [11-15]. However, not only reactogenicity but also sufficient immunogenicity of reassortant vaccine strains are the main requirements for LAIV. It was found that the immunogenicity of different live vaccine strains of genome formula $6: 2$ could vary within a wide range [16]. However, the question of inheritance of the immunogenic properties of the wild virus by vaccine strains is insufficiently studied.

When develop modern influenza vaccines it is essential to achieve a balance between the limited replication of the vaccine strain and its immunogenicity. Immunogenicity of vaccine candidates may depend on the ability of live vaccine strain to induce the response of early cytokines, and the relative sensitivity of the vaccine strain to anti-virus action of these cytokines [17]. 
It was shown in a number of papers [18-20] described the induction of cytokine production by vaccine strains of influenza viruses in vivo in mice, that in vaccinated mice the expression levels of proinflammatory cytokines and the levels of inflammation in the lungs were lower than in unvaccinated animals. At the same time, cold-adapted vaccine strains have caused a pronounced stimulation of the immune response, manifested in the activation of different chemokines and further activated T- and B-lymphocytes. Presumably, lower levels of production of pro-inflammatory cytokines after exposure the vaccine viruses are the cause of decrease the pathological effects and reduction sensitivity to secondary infections [21].

As of today, the ways how live influenza vaccine provides stimulation of all systems of the immune response and establishes an antiviral status of the body is not well understood. Most of the research profiles of early cytokines after exposure with vaccine strains of influenza viruses were carried out on murine and swine models [3], while in humans; this issue is very poorly studied.

The aim of this study was to investigate the early cytokine response in vitro and early protective activity in female CBA mice intranasally immunized with cold-adapted influenza vaccine strains with different genome compositions of $5: 3$ or $6: 2$. For experimental infection (challenge), pandemic influenza viruses A/South Africa/3626/13 (H1N1)pdm09 and A/New York/61/15 (H1N1)pdm09 were used.

\section{Materials and methods}

Viruses. The following influenza A viruses were used in this study: (i) wild-type influenza H1N1pdm09 strains A/South Africa/3626/13 (SA/wt) and A/New York/61/15 (NY/wt), (ii) cold-adapted ( $c a$ ) Leningrad/134/17/57 (H2H2) (Len/17) MDS and (iii) two SA H1N1pdm09 reassortant LAIV candidates with a different genome composition, LAIV SA 6:2rg and LAIV SA 5:3rg. H1N1pdm09 LAIV reassortants were generated by standard plasmid-based reverse genetics, as described elsewhere [13]. Both candidates inherited hemagglutinin (HA) and neuraminidase (NA) from A/South Africa/3626/13 (H1N1)pdm09 influenza virus and PB2, PB1, PA, $M$ and NS genes from A/Leningrad/134/17/57(H2N2) MDS. The gene encoding for the nucleoprotein of 5:3 reassortant virus was obtained from the A/South Africa/3626/13 (H1N1) and for a 6:2 virus - from the MDS. Preservation of attenuating mutations in reassortants was monitored by PCR-restriction (RLFP) analysis [22].

Viruses were grown in the allantoic cavity of 10-day-old embryonated hen's eggs at the temperature of $32{ }^{\circ} \mathrm{C}$ for 48 hours. Infectious allantoic fluid was divided into aliquots and stored at $-70{ }^{\circ} \mathrm{C}$. Fifty percent egg infectious dose $\left(\mathrm{EID}_{50}\right)$ titers were determined by titration of viruses in eggs and calculated by Reed and Muench method [23].

Mice. Female CBA mice aged 6-8 weeks were supplied by the laboratory breeding nursery "Rappolovo" (St. Petersburg Region).

Ethics approval. All procedures for the use and care of animals were approved by the Local Bioethical Committee of the Institute of Experimental Medicine (No. 3/17 from 30.11.2017).

Viral replication and neuroinvasion in mice. To determine virus infectivity and neuroinvasion, mice were lightly anesthetized with ether and inoculated intranasally with $50 \mu \mathrm{l}$ of phosphate-buffered saline (PBS) containing $6.0 \log _{10} \mathrm{EID}_{50}$ of each tested virus, divided equally between the nostrils. Viral load was measured in upper and lower respiratory tissue and brain tissue samples which were collected on days 3 and 6 post-infection, respectively. Tissue homogenates were prepared using a small bead mill TissueLyser LT (QIAGEN, Germany), in $1.0 \mathrm{ml}$ of sterile PBS containing antibiotic-antimycotic (Invitrogen, UK); the clarified supernatants were titrated in eggs at a temperature that allowed determination of virus titers.

Immunization and early protection activity study. Mice were randomly distributed into three groups, 20 mice each. Mice of two groups were intranasally immunized with virus-containing allantois fluid diluted on PBS of LAIV SA 5:3rg or LAIV SA 6:2rg at a dose of $6.0 \log _{10} \mathrm{EID}_{50}$ under mild ether anesthesia. The third group of mice served as a control and intranasally received $50 \mu \mathrm{l}$ PBS per mouse intranasally (mock infected mice). On day 3 after immunization animals of each group were divided in half and intranasally infected with pandemic influenza viruses A/South Africa/3626/13 (H1N1)pdm09 or A/New York/61/15 (H1N1) pdm09 at a dose of $10^{6}$ EID $_{50}$ under mild ether anesthesia. On day 3 after experimental infection (on day 6 after immunization), lungs from five mice of each group were collected and used to assess the replication of wild-type influenza viruses. The rest 10 mice of each group were monitored for 10 days to study weight loss and mortality rate.

Cells. THP-1, human alveolar macrophage cell line (ATCC\#TIB-202), was used to study the production of early cytokines. THP-1 cells were maintained in RPMI-1640 tissue culture medium supplemented with $10 \%$ fetal calf serum, antibiotics, $2 \mathrm{mM}$ L-glutamine, $0.1 \mathrm{mM}$ non-essential amino acids, and $1.0 \mathrm{mM}$ sodium pyruvate. Approximately $1 \times 10^{6}$ cells were infected with viruses at 1.0 multiplicity of infection (MOI) for 1 hour, washed and cultured in 24-well tissue culture plates for 3 and 24 hours. Culture supernatants were collected and stored at the temperature 
of $-70{ }^{\circ} \mathrm{C}$. Cell lysates were collected at 3 and 24 hours for cytokine assays.

Cytokines gene expression. The levels of cytokines gene expression were determined by realtime polymerase chain reaction (rRT-PCR) as described previously [24]. Briefly, the RNA extraction was performed using RNeasy Mini Spin Column (QIAGEN, Hilden, Germany). The RNA was eluted in $50 \mu \mathrm{l}$ of RNAse-free water and was used as the template for rRT-PCR. For cDNA synthesis, reverse transcription (RT) with $100 \mathrm{pg}$ of total RNA was performed using oligo(dt) primers and random hexamers mix and the SuperScript III kit (Invitrogen, Carlsbad, CA, USA). rRT-PCR was performed in a CFX96 (Biorad, Hercules, CA, USA) thermocycler using SybrGreen as fluorogenic probe in $25 \mu \mathrm{l}$ reactions containing $5 \mu \mathrm{l}$ cDNA sample, 10 supermix (Thermo Scientific, Waltham, MA USA), 50 pmol of forward and reverse primers and nuclease-free water (Applied Biosystems, USA). RT-qPCR assays for interferon I alpha (IFN-I-alpha), interferon I beta (IFN-I-beta) using glyceraldehyde 3-phosphate dehydrogenase (GAPDH) for normalization. Melting curve analysis was performed for each primer pair at the end of the reaction to confirm the specificity of the assay. All rRT-PCR assays were performed in duplicates. Data were analyzed using the comparative $\mathrm{Ct}$ method $(\mathrm{Ct}$ : the number of PCR cycles which is necessary to achieve a given level of fluorescence), normalized to GAPDH and HPRT, and presented as the fold changes in gene expression of treated cells, relative to the control non-treated cells.

\section{Results and discussion}

\section{Role of early cytokines and chemokines in influenza virus infection and vaccination}

Influenza A viruses cause the production of chemokines such as MIP- $1 \alpha$, RANTES, IP-10, proinflammatory cytokines such as IL-6, TNF- $\alpha$ and interferons in the early stages of infection which are responsible for all successive stages of the body's antiviral response to influenza virus infection, ensuring virus containment and removal [25]. Cytokines are the key mediators that not only induce the defense mechanisms of primary and secondary viral infection but also regulate the immune response to vaccination. Different cell types can induce cytokine production in response to viral infection. The spectrum of cytokines produced by the cell depends on the nature, duration, and intensity of the pathogen, as well as on the presence of additional mediators: other cytokines, hormones and intercellular interactions [3].

Interferon system is the main humoral factor of congenital antiviral protection. Interferons-I
(IFN- $\alpha$, IFN- $\beta$ ) are produced directly in response to the introduction of the virus, and then partially suppress the replication of viruses and limit the spread of viral offspring. Synthesis of the type I interferons leads to the production of IL-6, IL-12, IL-18, and TNF- $\alpha$. IFN- $\alpha$ and IFN- $\beta$, which provide antiviral effects in both infected and uninfected cells and regulate the innate and adaptive immune response against viral pathogens in various ways [26].

In the development of influenza vaccines, it is important to create appropriate in vivo and in vitro models to study the individual immunostimulatory properties of vaccine strains and their interaction with components of innate and acquired immunity. The study of gene expression is also considered to be a promising approach of molecular genetic analysis to determine the immunomodulating effect of vaccine strains. Since alveolar macrophages are the first line of defense of the respiratory tract against pathogens, including influenza viruses, the study of factors produced by these cells can deepen our understanding of the pathogenesis of infection and the mechanisms of immunity.

Unlike epithelial cells, macrophages make an important contribution to the secretion of antiviral and immunostimulatory cytokines in influenza infection. It was showed that in the early stages of infection macrophages produce a significant greater levels of antiviral cytokines such as IFN- $\alpha$ and chemokines, involved in the migration of leukocytes from circulation to the site of inflammation compare to epithelial cells. Some early studies showed that human macrophages, after exposure with both live and inactivated influenza A viruses, produced interferons type I 24 hours after vaccination. Thus, virus replication was not a necessary condition in this system, although macrophages treated with the inactivated virus produced fewer interferons than macrophages treated with attenuated LAIV viruses [27].

In the present study, the level of cytokines (IFN- $\alpha$ and IFN- $\beta$ ) produced by THP- 1 cells in response to influenza A virus infection was studied to assess the factors of innate immunity in the immune system cells infected with epidemic and vaccine influenza A viruses.

Previously we demonstrated that on a mouse model more attenuated influenza viruses replicate in the lower respiratory tract to the less extent compare to less attenuated variants [28]. The correlation between attenuation levels of cold-adapted influenza viruses and the levels of their replication was established. Thus, mice consider as a suitable model for studying the level of attenuation of coldadapted viruses.

In our earlier paper we described the role of introduction NP gene from wild-type virus to vaccine

Tom
Volume

Bыпуск
Issue

2019 ISSN 1608-4101 (Print) 
safety and stimulation of adaptive immunity. One dose of either LAIV SA 6:2rg or LAIV SA 5:3rg candidates elicited a measurable antibody response, which was boosted by a second vaccine dose. Studies of the cell-mediated immune response in mice revealed that the 5:3 variant provoked greater production of specific $\mathrm{CD} 8^{+}$T-lymphocytes to wild-type influenza virus than the 6:2 variant. An in vivo virus-specific cytotoxic T-lymphocyte assay showed that, compared with naive mice, more effective killing of wild-type virus-infected target cells was seen in mice immunized with the 5:3 LAIV. These data correlate with the observed $100 \%$ protection from death in mice given either the $6: 2$ or the 5:3 LAIV following lethal challenge with homologous A/South Africa/3626/2013 and drifted A/New York/61/2015 viruses. The 5:3 LAIV candidate afforded greater protection against infection and severe illness than the 6:2 LAIV. Our findings confirm that both candidate LAIVs are safe and immunogenic, and protect against homologous influenza virus infection in mice. Inclusion in an LAIV of the NP gene from wild-type influenza virus is a new approach to inducing cross-reactive cell-mediated immune responses and cross-protection against pandemic influenza [29].

In the present study, we confirmed our past results of limited viral replication in the mice lungs LAIV reassortants and studied innate immunity and early protection after immunization. We have shown that reassortants with different genome formula (6:2 or 5:3), as well as A/Leningrad/134/17/57 (H2N2) MDS, replicated to identical levels in the upper and lower airways of mice. In contrast, the wild-type virus showed 1000-10000 times more efficient replication in the lungs and nasal turbinates on day 3 after immunization and was still detected at high levels on day 6. It is obvious that this could be due to the attenuated properties of the LAIV [12].

According to the results of the experimental study of early protective activity of LAIV with different genome formulas, we showed that the most pronounced protective effect was observed on day 6 after immunization. Thus, the survival rate reached 90\% after experimental infection with wild-type virus A/South Africa/3626/13 (H1N1)pdm09 in a group of mice pre-immunized with LAIV SA 6:2rg. In the group of mice immunized with the LAIV SA 5:3rg, 20\% mortality was recorded compared to the group of control animals, where mortality reached $60 \%$. In addition, our data showed that immunization of mice with LAIV reduced replication of wild-type A/South Africa/3626/13(H1N1) pdm09 and A/New York/61/15(H1N1)pdm09 in their lungs to low values. Reassortants LAIV did not differ statistically on these levels. This data shows that animals were protected from death in the early stages after immunization with the LAIVs, although mice were not completely protected from infection with wild-type viruses.

The observed protective effect can be explained by the production of early cytokines, particularly type I interferons, by the respiratory tract cells after immunization of the LAIV. As a result of the study of the expression of IFN- $\alpha$ and IFN- $\beta$ genes on THP-1 cells by real-time polymerase chain reaction with reverse transcription, we found that macrophages infected with vaccine strains of LAIV were characterized by the level of expression of IFN- $\alpha$, comparable with the level of infection with wild type virus A/South Africa/3626/13(H1N1) pdm09, which may indicate that stimulation of IFN-I expression is caused by surface proteins of influenza A virus.

Our findings suggest that intranasal immunization with live influenza vaccines may modulate the innate immune response, thereby reducing primary viral infection. Vaccination against influenza is limited to the period of the seasonal epidemic influenza. Data on the modeling of influenza infection in mice clearly show that the use of LAIV has a protective effect against the homologous epidemic influenza virus in the first days after intranasal administration [30].

Given that specific antibodies are formed 2 to 4 weeks after immunization [31], the effect of early nonspecific protection provided by the LAIV is particularly important for vaccination during the circulation of not only influenza viruses, but also the etiological agents of other respiratory infections. Evaluation of the expression of early cytokines in viral infection and vaccination will contribute to a better understanding of the interaction of immune mechanisms and independent functions of cytokines in the regulation of nonspecific protection against viral infections.

\section{Vaccine replication and neuroinvasion in mice}

The LAIV SA 6:2rg, LAIV SA 5:3rg and Len/17 MDS influenza viruses, administered at a dose of $6 \log _{10} \mathrm{EID}_{50}$, replicated in mouse lungs to a level of 2.8-3.7 $\log _{10} \mathrm{EID}_{50} / \mathrm{ml}$ on day 3 after inoculation (Fig. 1, a). On day 6, replication of the cold-adapted viruses in the lungs had decreased to $2.0-2.3 \log _{10} \mathrm{EID}_{50} / \mathrm{ml}$. The replication of the vaccine reassortants and the MDS in the nasal turbinates showed the same trend $-3.0-3.2 \log _{10} \mathrm{EID}_{50} / \mathrm{ml}$ on day 3 , and 2.0-2.2 $\log _{10} \mathrm{EID}_{50} / \mathrm{ml}$ on day 6 . In contrast, the wild-type virus A/South Africa/3626/2013 (H1N1), showed up to $10^{3}-10^{4}$ higher replication in the lungs and nasal turbinates of mice on day 3 $\left(6.9 \log _{10} \mathrm{EID}_{50} / \mathrm{ml}\right)$, and on day 6 was still replicating at high levels in the upper and lower respiratory tracts $\left(5.8 \log _{10} \mathrm{EID}_{50} / \mathrm{ml}\right)$ (Fig. 1, b). There was no significant difference between the LAIV viruses and 

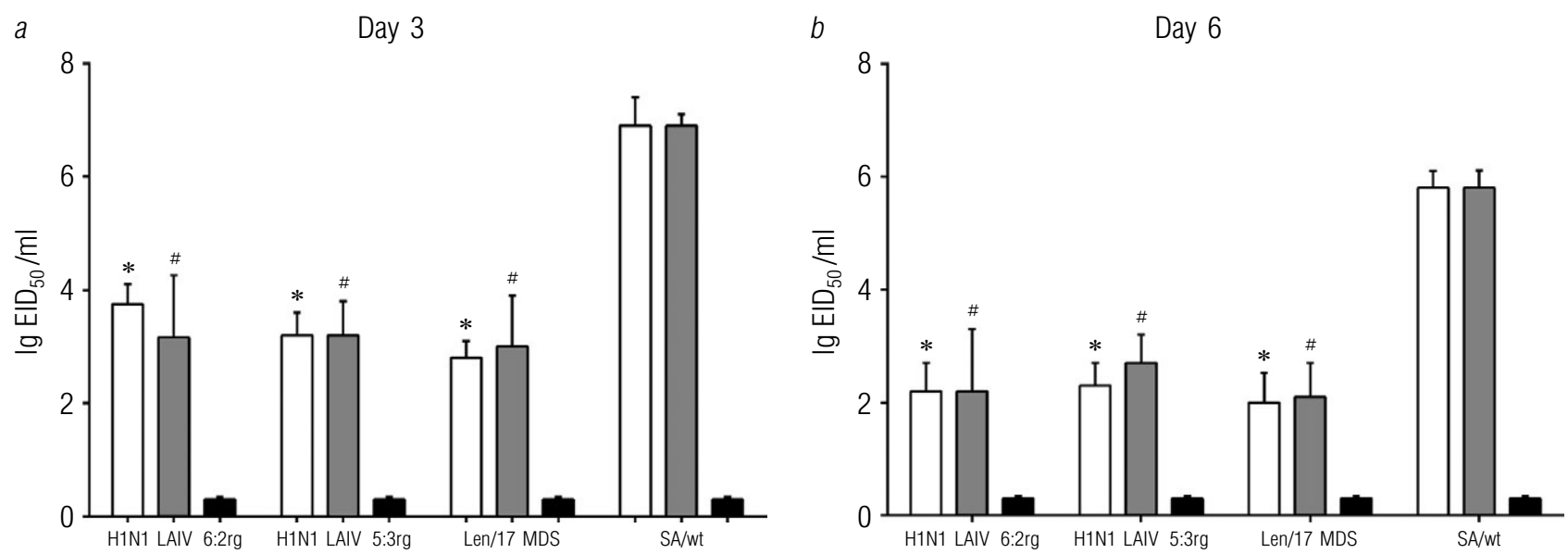

Fig. 1. Replication of H1N1 LAIVs, Len/17 MDS and wild-type influenza viruses in the upper and lower respiratory tract of mice and neuroinvasion: $a$ - on day 3 after infection; $b-$ on day 6 after infection. White bars - lungs; grey bars nasal turbinates; black bars - brain. Averaged data on 5 mice \pm SEM were presented. The significance of differences was determined by the method of univariate analysis of variance (ANOVA). ${ }^{*} p<0.05$ compared to replication of pandemic influenza virus type A/South Africa/3626/13 (H1N1)pdm09 in mouse lungs; ${ }^{*} p<0.05$ compared to replication of pandemic influenza virus type A/South Africa/3626/13 (H1N1)pdm09 in nasal turbinates of mice

the MDS with regard to replication in the upper respiratory tract of mice. Both the 6:2 and the 5:3 reassortants were indistinguishable from the MDS in terms of replication in the lungs and noses of mice on day 3 and on day 6 after inoculation. No virus was found in the brain tissue of immunized mice in any of the studied groups on days 3 and 6 (in undiluted samples). Thus, both vaccine candidates were shown to be safe and identical to the Len/17 MDS in terms of replication in the upper and lower respiratory tract of mice; both lacked neuroinvasive capacity and failed to replicate in the mouse brain.

\section{Early protective effect of pandemic H1N1 LAIVs}

To investigate the early protective activity of pandemic H1N1 LAIVs, the survival rates in mice up to 10 days after their challenge infection with wild-type influenza A viruses were determined. The ratio of the number of surviving mice to the total number of mice in the groups was used as an indicator of survival. The results are presented in Table 1.

The Table 1 shows that $6: 2$ and 5:3 reassortants equally well protected mice (survival rate $100 \%$ ) from experimental infection with influenza virus $\mathrm{A} / \mathrm{New}$
York/61/15 (H1N1)pdm09. After an experimental infection of vaccinated groups of animals with virus A/South Africa/3626/13(H1N1)pdm09, survival was equal to $90 \%$ and $80 \%$ for vaccine strains with genome formula $6: 2$ and 5:3, respectively, while in control nonimmunized groups mortality was observed $-40 \%$ and $60 \%$ when infected with influenza virus strain A/New York/61/15 (H1N1)pdm09 and A/South Africa/3626/13 (H1N1)pdm09, respectively. The data obtained may indicate a sufficiently high virulence of influenza virus $\mathrm{A} /$ South Africa/3626/2013 (H1N1)pdm09.

In addition, mice lungs were collected to study the infectivity of wild-type strains on day 3 after experimental infection of mice with two strains of pandemic influenza viruses (A/South Africa/ 3626/13(H1N1)pdm09 and A/New York/61/15 (H1N1)pdm09). After homogenization and subsequent titration of probes on 10-day chicken embryos, the viral replication of pandemic viruses in the lungs was determined and expressed in $\log _{10} \mathrm{EID}_{50} / \mathrm{ml}$. The results are shown in Fig. 2. The data reliably showed the significant decrease in the replication of pandemic influenza virus A/South Africa/3626/13 (H1N1)pdm09 to 3.22 and $4.42 \log _{10} \mathrm{EID}_{50} / \mathrm{ml}$ in the lungs of mice immunized

Table 1

Early protective activity of LAIV in mice for 10 days after their challenge with wild influenza viruses

\begin{tabular}{|l|c|c|c|c|}
\hline \multirow{2}{*}{ Group } & \multicolumn{4}{|c|}{ Challenge virus } \\
\cline { 2 - 5 } & \multicolumn{2}{|c|}{ A/South Africa/3626/13 (H1N1)pdm09 } & \multicolumn{2}{c|}{ A/New York/61/15 (H1N1)pdm09 } \\
\cline { 2 - 5 } & Survival (alive/total) & Survival, $\%$ & Survival (alive/total) & Survival, \% \\
\hline LAIV SA 5:3rg & $8 / 10$ & 80 & $10 / 10$ & 100 \\
\hline LAIV SA 6:2rg & $9 / 10$ & 90 & $10 / 10$ & 100 \\
\hline Mock infected mice & $4 / 10$ & 40 & $6 / 10$ & 60 \\
\hline
\end{tabular}



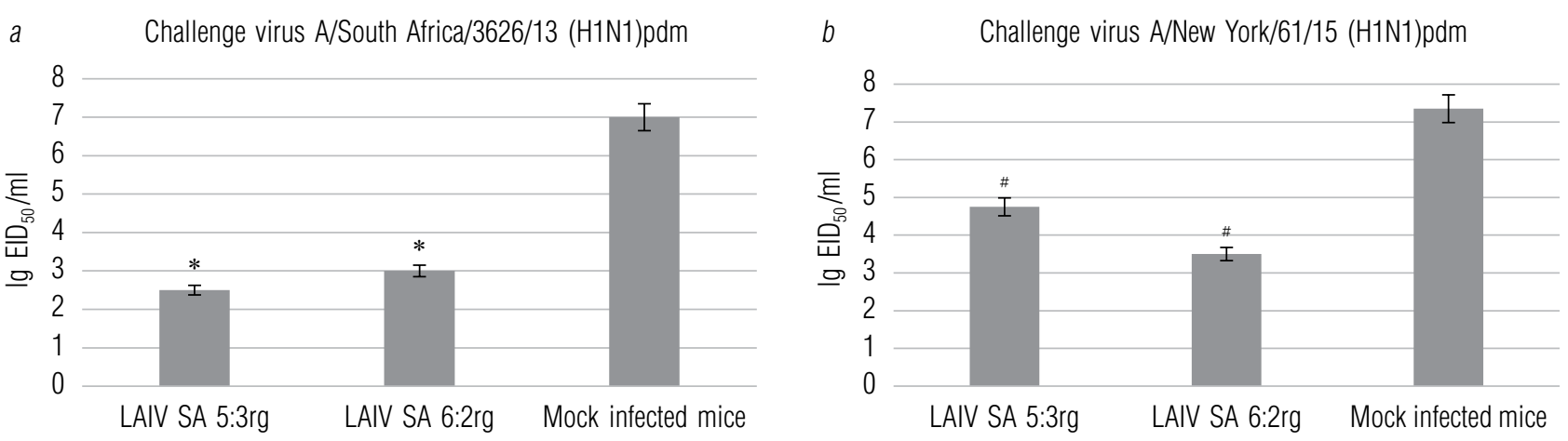

Fig. 2. Reproduction of pandemic influenza A viruses in the lungs on day 6 after immunization: $a$ - mice challenged with A/South Africa/3626/13 (H1N1)pdm; $b-$ mice challenged with A/New York/61/15 (H1N1)pdm. Averaged data for 5 mice \pm SEM are presented. The significance of the differences was determined by univariate analysis of variance (ANOVA). ${ }^{*} p<0.05$ compared to replication of pandemic influenza virus A/South Africa/3626/13 (H1N1)pdm09 in the lungs of control unimmunized mice. ${ }^{*} p<0.05$ compared to replication pandemic influenza virus A/New York/61/15 (H1N1)pdm09 in the lungs of control non-unimmunized mice

with a vaccine strain with genome formula $5: 3$ and 6:2 respectively (Fig. 2,a). Also, we noticed significant reduction in replication of pandemic influenza virus $\mathrm{A} / \mathrm{New}$ York/61/15 (H1N1)pdm09 in mouse lungs to values of 4.05 and $3.25 \log _{10} \mathrm{EID}_{50} / \mathrm{ml}$ when immunized with a vaccine strain with the genome formula $5: 3$ and $6: 2$, respectively, on day 6 after immunization mice with LAIV. Otherwise, it can be seen that the replication of wild-type A virus A/South Africa/3626/13 (H1N1)pdm09 and A/New York/61/15 (H1N1)pdm09 in the lungs of non-immunized control mice reached to values (7.1 and $7.35 \log _{10} \mathrm{EID}_{50} / \mathrm{ml}$ ), respectively.

Thus, both studied reassortant vaccine strains have protective activity and protect against death infection with pathogenic for mice influenza $\mathrm{A}(\mathrm{H} 1 \mathrm{~N} 1)$ pandemic viruses.

\section{Study of type I interferons gene expression (IFN- $\alpha$ and IFN- $\beta$ ) in vitro}

To study the effect of LAIV or wild-type viruses on cytokine expression profile in infected cells, interferons-I (IFN- $\alpha$ and IFN- $\beta$ ) genes expression level as the most important factor of antiviral protection was determined. After 3 hours post-infection of THP-1 cells with influenza viruses, the total RNA was isolated and rRT-PCR was performed to determine the expression level of interferon-I (IFN- $\alpha$ and IFN- $\beta$ ) genes. The results are shown in Fig. 3.

It has been shown that more pronounced immunostimulating effect in terms of IFN- $\alpha$ and IFN- $\beta$ expression in THP-1 cells was registered after stimulation by positive control-lipopolysaccharide (LPS) at a concentration of $100 \mu \mathrm{g} / \mathrm{ml}$. In this case, the expression level reached 2.92 and 1.75 fold for IFN- $\alpha$ and IFN- $\beta$, respectively. We also noticed that the level of expression of IFN- $\alpha$ reached good values in macrophages infected with the studied viruses, A/South Africa/3626/13
(H1N1)pdm09, Len/17 MDS, LAIV SA 6:2rg and LAIV SA 5:3rg (1.03, 1.6, 0.97 and 1.78, folds respectively). Differences between the SA/wt virus and LAIV SA 5:3 rg reassortant in terms of stimulation IFN- $\alpha$ genes were not significant $(p>0.05)$. Overwise, reassortant LAIV SA 6:2rg and Len/17 MDS stimulated IFN- $\alpha$ genes to the statistically great extent compare to SA/wt virus $(p>0.05)$.

According to the data presented in Figure 3, IFN- $\beta$ genes expression by macrophages after infection with the studied viruses $\mathrm{A} /$ South Africa/3626/13 (H1N1)pdm09, LAIV SA 6:2rg and LAIV SA 5:3rg were 0.94, 0.94, 0.97 and 0.6 fold respectively. Differences between them were not significant $(p>0.05)$. However, the differences in the level of expression of this cytokine between the Len/17 MDS and LAIV SA 6:2rg were significant $(p=0.001)$ and the expression level reached 1.33 and 0.94 fold respectively.

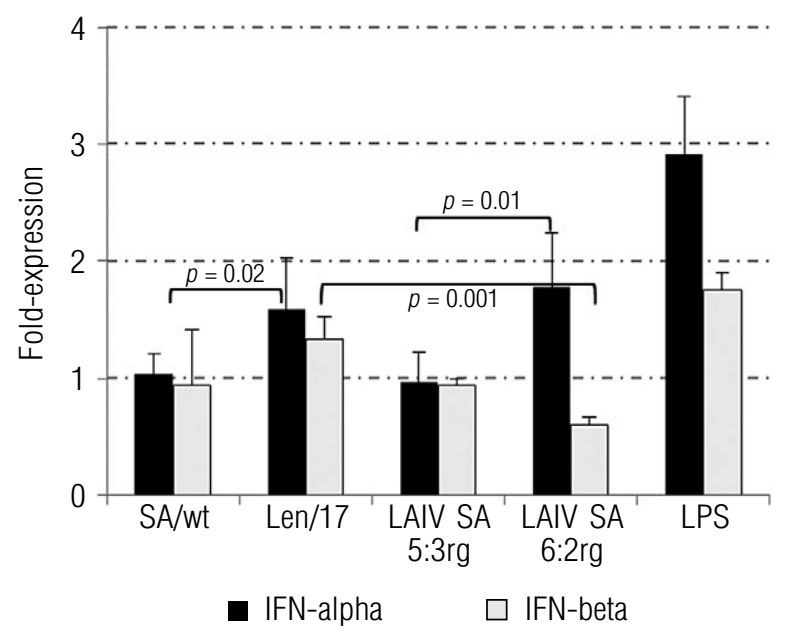

Fig. 3. Level of expression of IFN- $\alpha$ and IFN- $\beta$ genes in human lung macrophage cell line THP-1 after infection with attenuated or wild-type influenza A viruses. Mean data on 4 experiments \pm SEM are presented 


\section{Conclusion}

It was found that both tested LAIV reassortants were similar to the A/Leningrad/134/17/57 (H2N2) MDS in terms of replication in the respiratory tract of mice and showed no neuroinvasive capacity. Results of survival of mice during 10 days after challenge infection with pandemic influenza viruses as well as decreasing replication of pandemic viruses in lungs of mice on day 6 after immunization demonstrated a significant early protective effect of reassortant LAIVs, which may be associated with the induction of cytokines. Reassortants LAIV did not differ statistically on these values. Human lung macrophage cells THP-1 exposed with vaccine strains of LAIV with the genome formula 6:2 and 5:3 had level of expression of IFN-genes in vitro, comparable to the level of expression of these genes when infected with wild type virus A/South Africa/3626/13 (H1N1)pdm09, which may indicate the involvement of surface proteins of influenza A virus in the process of stimulation of these genes.

Taking together, these data support the usefulness LAIV, which can provide protection soon after vaccination against infection with homologous and drifted variants of pandemic influenza viruses due to stimulation factors of innate immunity.

\section{References}

1. World Health Organization. Influenza Seasonal [Internet]. WHO; 2019 [cited 2018 November 6]. Available from: http:// www.who.int/mediacentre/factsheets/fs211/en/index.html.

2. $W H O / / V B / 06.13$. Global influenza pandemic action plan to increase vaccine supply [Internet]. Geneva: WHO; 2006. Available from: http://whqlibdoc.who.int/hq/2006/WHO_ IVB_06.13_eng.pdf.

3. Julkunen I, Sareneva T, Pirhonen J, et al. Molecular pathogenesis of influenza A virus infection and virus-induced regulation of cytokine gene expression. J Cytokine Growth Factor Rev. 2001;12(2-3):171-180. https://doi.org/10.1016/ S1359-6101(00)00026-5.

4. Kreijtz JH, Fouchier RA, Rimmelzwaan GF. Immune responses to influenza virus infection. Virus Research. 2011;162(1-2):19-30. https://doi.org/10.1016/j.virusres.2011.09.022.

5. Hopkins SJ. The pathophysiological role of cytokines. Leg Med (Tokyo). 2003;5 Suppl 1:S45-57. https://doi. org/10.1016/S1344-6223(02)00088-3.

6. Feghali CA, Wright TM. Cytokines in acute and chronic inflammation. Front Biosci. 1997;2(4):d12-26. https://doi. org/10.2741/a171.

7. Rudenko LG, Alexandrova GI. Current strategies for the prevention of influenza by the Russian cold-adapted live influenza vaccine among different populations. International Congress Series. 2001;1219:945-950. https://doi.org/10.1016/ S0531-5131(01)00661-6.

8. Nichol KL. Live attenuated influenza virus vaccines: new options for the prevention of influenza. Vaccine.
2001;19(31):4373-4377. https://doi.org/10.1016/S0264410X(01)00143-8.

9. Rudenko LG, Arden NH, Grigorieva E, et al. Immunogenicity and efficacy of Russian live attenuated and US inactivated influenza vaccines used alone and in combination in nursing home residents. Vaccine. 2000;19(2-3):308-318. https://doi. org/10.1016/S0264-410X(00)00153-5.

10. Isakova-Sivak I, Rudenko L. Safety, immunogenicity and infectivity of new live attenuated influenza vaccines. Expert Rev Vaccines. 2015;14(10):1313-1329. https://doi.org/10.1586/ 14760584.2015.1075883.

11. Isakova-Sivak I. Live attenuated Influenza vaccines against highly pathogenic H5N1 avian influenza: development and preclinical characterization. Journal of Vaccines and Vaccination. 2013;4(8):40. https://doi.org/10.4172/21577560.1000208.

12. Klimov Al, Cox NJ, Yotov WV, et al. Sequence changes in the live attenuated, cold-adapted variants of influenza A/Leningrad/134/57 (H2N2) virus. Virology. 1992;186(2):795797. https://doi.org/10.1016/0042-6822(92)90050-Y.

13. Isakova-Sivak I, Chen LM, Matsuoka Y, et al. Genetic bases of the temperature-sensitive phenotype of a master donor virus used in live attenuated influenza vaccines: A/Leningrad/134/17/57 (H2N2). Virology. 2011;412(2):297-305. https://doi.org/10.1016/j.virol.2011.01.004.

14. Kiseleva IV, Voeten JT, Teley LC, et al. PB2 and PA genes control the expression of the temperature-sensitive phenotype of cold-adapted B/USSR/60/69 influenza master donor virus. J Gen Virol. 2010;91(Pt 4):931-937. https://doi. org/10.1099/vir.0.017996-0.

15. Klimov Al, Kiseleva IV, Alexandrova GI, Cox NJ. Genes coding for polymeraze proteins are essential for attenuation of the cold-adapted A/Leningrad/134/17/57 (H2N2) influenza virus. International Congress Series. 2001;1219:955-959. https://doi.org/10.1016/S0531-5131(01)00369-7.

16. Rudenko LG, Kiseleva IV, Larionova NV, et al. Analysis of some factors influencing immunogenicity of live coldadapted reassortant influenza vaccines. International Congress Series. 2004;1263:542-546. https://doi.org/10.1016/ j.ics.2004.02.046.

17. Rekstin AR, Kiseleva IV, Klimov Al, et al. Interferon and other proinflamatory cytokine responses in vitro following infection with wild-type and cold-adapted reassortant influenza viruses. Vaccine. 2006;24(44-46):6581-6584. https://doi. org/10.1016.vaccine.2006.05.091.

18. Conn CA, McClellan JL, Maassab HF, et al. Cytokines and the acute phase response to influenza virus in mice. $A m \mathrm{~J}$ Physiol. 1995;268(1 Pt 2):R78-84. https://doi.org/10.1152/ ajpregu.1995.268.1.R78.

19. Ramakrishnan A, Althoff KN, Lopez JA, et al. Differential serum cytokine responses to inactivated and live attenuated seasonal influenza vaccines. Cytokine. 2012;60(3):661-666. https://doi.org/10.1016/j.cyto.2012.08.004.

20. Tamura S. Studies on the usefulness of intranasal inactivated influenza vaccines. Vaccine. 2010;28(38):6393-6397. https://doi.org/10.1016/j.vaccine.2010.05.019.

21. Lanthier PA, Huston GE, Moquin A, et al. Live attenuated influenza vaccine (LAIV) impacts innate and adaptive immune 
responses. Vaccine. 2011;29(44):7849-7856. https://doi. org/10.1016/j.vaccine.2011.07.093.

22. Klimov Al, Cox NJ. PCR restriction analysis of genome composition and stability of cold-adapted reassortant live influenza vaccines. J Virol Methods. 1995;52(1-2):41-49. https:// doi.org/10.1016/0166-0934(94)00133-2.

23. Reed LJ, Muench $\mathrm{H}$. A simple method of estimating fifty percent endpoints. Am J Epidemiol. 1938;27(3):493-497. https://doi.org/10.1093/oxfordjournals.aje.a118408.

24. Desheva YA, Leontieva GF, Kramskaya TA, et al. Factors of early protective action of live influenza vaccine combined with recombinant bacterial polypeptides against homologous and heterologous influenza infection. Heliyon. 2019;5(2):e01154. https://doi.org/10.1016/j.heliyon.2019. e01154.

25. Rodgers BC, Mims CA. Influenza virus replication in human alveolar macrophages. J Med Virol. 1982;9(3):177-184. https://doi.org/10.1002/jmv.1890090304.

26. Shim JM, Kim J, Tenson T, et al. Influenza virus infection, interferon response, viral counter-response, and apoptosis. Viruses. 2017;9(8). pii: E223. https://doi.org/10.3390/ v9080223.
27. McNab F, Mayer-Barber K, Sher A, et al. Type I interferons in infectious disease. Nat Rev Immunol. 2015;15(2):87-103. https://doi.org/10.1038/nri3787.

28. Киселева И.В., Крутикова Е.В., Рекстин А.Р., и др. Мыши как модель для изучения степени аттенуации холодоадаптированных штаммов вируса гриппа // Медицинский академический журнал. - 2017. - Т. 17. - № 2. - С. 67-75. [Kiseleva IV, Krutikova EV, Rekstin AR, et al. Mouse model for the study of attenuation of cold-adapted influenza viruses. Medical academic journal. 2017;17(2):67-75. (In Russ.)]

29. Rekstin A, Isakova-Sivak I, Petukhova G, et al. Immunogenicity and cross protection in mice afforded by pandemic H1N1 live attenuated influenza vaccine containing wild-type nucleoprotein. Biomed Res Int. 2017;2017:9359276. https:// doi.org/10.1155/2017/9359276.

30. Jin H, Subbarao K. Live attenuated influenza vaccine. Curr Top Microbiol Immunol. 2015;386:181-204. https://doi. org/10.1007/82_2014_410.

31. Cate TR, Couch RB, Parker D, Baxter B. Reactogenicity, immunogenicity, and antibody persistence in adults given inactivated influenza virus vaccines - 1978. Rev Infect Dis. 1983;5(4):737-747. https://doi.org/10.1093/clinids/5.4.737.
Andrey R. Rekstin - PhD, Leader Scientist, Department of Virology, Institute of Experimental Medicine, Saint Petersburg, Russia. E-mail: arekstin@yandex.ru.

Julia A. Desheva - Doctor of Medical Science, Associate Professor, Leader Scientist, Department of Virology, Institute of Experimental Medicine, Saint Petersburg, Russia. E-mail: desheva@mail.ru.
Андрей Роальдович Рекстин - канд. биол. наук, ведущий научный сотрудник, отдел вирусологии, ФГБНУ «Институт экспериментальной медицины», Санкт-Петербург. E-mail: arekstin@yandex.ru.

Юлия Андреевна Дешева - д-р мед. наук, доцент, ведущий научный сотрудник, отдел вирусологии, ФГБНУ «Институт экспериментальной медицины», Санкт-Петербург. E-mail: desheva@mail.ru. 
Irina $V$. Kiseleva - Doctor of Biological Sciences, Professor, Head of the Laboratory, Department of Virology, Institute of Experimental Medicine, Saint Petersburg, Russia. E-mail: irina.v.kiseleva@mail.ru.

Irina N. Isakova-Sivak - Doctor of Biological Sciences, Head of the Laboratory, Department of Virology, Institute of Experimental Medicine, Saint Petersburg, Russia. E-mail: isakova.sivak@gmail.com.
Ирина Васильевна Киселева - д-р биол. наук, профессор, заведующий лабораторией, отдел вирусологии, ФГБНУ «Институт экспериментальной медицины», Санкт-Петербург. E-mail: irina.v.kiseleva@mail.ru.

Ирина Николаевна Исакова-Сивак - д-р биол. наук, заведующий лабораторией, отдел вирусологии, ФГБНУ «Институт экспериментальной медицины», Санкт-Петербург. E-mail: isakova.sivak@gmail.com.

\section{Corresponding author / Контактное мицо}

Andrey R. Rekstin / Андрей Роальдович Рекстин

E-mail: arekstin@yandex.ru 